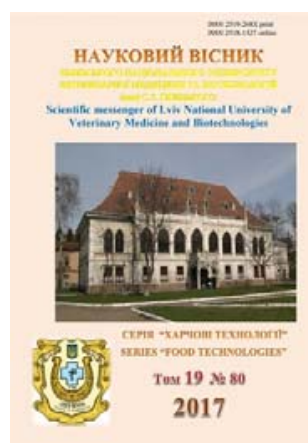

Науковий вісник Львівського національного університету ветеринарної медицини та біотехнологій імені С.З. Гжицького

Scientific Messenger of Lviv National University of Veterinary Medicine and Biotechnologies

doi:10.15421/nvlvet8007

ISSN 2519-268X print

ISSN 2518-1327 online

$\underline{\text { http://nvlvet.com.ua/ }}$

УДК 621.37:637.142

\title{
Удосконалення технології м'якого кисломолочного сиру підвищенням біологічної цінності
}

\author{
М.М. Самілик \\ m.samilyk@ukr.net \\ Сумський національний аграрний університет, \\ вул. Г. Кондратьєва, 160, м Суми, 40021, Україна
}

\begin{abstract}
Розглянуто склад молока та молочних продуктів. Акцентовано увагу на біологічній цінності і фізіологічному значенні сирів, оскільки вони містять увесь спектр поживних речовин, в тому числі й незамінних, необхідних людині для життєво важсливих процесів. 3 огляду на узагальнення наукових позицій щедо необхідності надання продуктам функціональних властивостей виникає потреба удосконалення рецептури та традиійних методів виробництва сиру. Важливо, щуо це відповідає основним принципам і напрямам держсавної політики у сфері здорового харчування. У статті запропоновано принципово нову рецептуру і технологію виробництва кисломолочного м'якого сиру підвищеної біологічної цінності збагаченого вітамінами, мікроелементами, вільними амінокислотами, харчовими волокнами. Для сиру, виготовленого за удосконаленою технологією, передбачено використання експериментальної назви «Любомир». Представлено узагальнену функиіональну схему виробництва сиру кисломолочного м'якого. Висока біологічна иінність сиру, отриманого запропонованим способом, обумовлена хімічним складом основних компонентів. Як компоненти запропоновано використовувати родзинки із зеленого винограду, волоські горіхи, яйчя курячі і перераховано, джерелом яких пластичних, енергетичних та захисних речовин вони є. Висвітлено фізіолого-гігієнічне значення нутрієнтів, що входять до їх складу. Окреслено висновки та основні завдання подальших досліджень.

Ключові слова: сир кисломолочний м'який, формування голівок, теплова обробка, охолодження, молоко, яйця, горіхи, родзинки, вершки, вітаміни, мікроелементи, вільні амінокислоти.
\end{abstract}

\section{Усовершенствование технологии мягкого кисломолочного сыра повышением биологической ценности}

\author{
М.M. Самилык \\ m.samilyk@ukr.net
}

Сумский наииональныий аграрний университет,

ул. Г. Кондратьева, 160, г. Сумы, 40021, Украина

\begin{abstract}
Рассматривается состав молока и молочных продуктов. Акцентировано внимание на биологической иенности и физиологическом значении сыров, так как они содержат весь спектр питательных веществ, в том числе и незаменимых, необходимых человеку для жизненно важных прочессов. Принимая во внимание обобщение научных позиций о необходимости придания продуктам функциональных свойств, возникает необходимость усовершенствования рецептуры и традиционных методов производства сыра. Важно, что это соответствует основным принципам и направлениям государственной политики в сфере здорового питания. В статье предложена принципиально новая рецептура и технология производства кисломолочного мягкого сыра повышенной биологической ценности, обогащенного витаминами, микроэлементами, свободными аминокислотами, пищевыми волокнами. Для сыра, который сделан по усовершенствованной технологии, предусмотрено использование экспериментального названия «Любомир». Представлена обобщенная функииональная схема производства мягкого кисломолочного сыра. Высокая биологическая ценность сыра, полученного предложенным способом, обусловлена химическим составом основных компонентов. В качестве компонентов предусмотрено использование изюма из белого
\end{abstract}

Citation:

Samilyk, M. (2017). Improving the technology of soft sour milk cheese by increasing biological value. Scientific Messenger LNUVMB, 19(80), 33-37. 
винограда, грецких орехов, яиц куриных и перечислено, источником каких пластических, энергетических и защчитных веществ они являются. Освещено физиолого-гигиеническое значение нутриентов, входящих в их состав. Определень выводы и основные задачи дальнейших исследований.

Ключевые слова: сыр кисломолочный мягкий, формование головок, тепловая обработка, охлаждение, молоко, яйца, орехи, изюм, сливки, витамины, микроэлементы, свободные аминокислоты.

\title{
Improving the technology of soft sour milk cheese by increasing biological value
}

\author{
M. Samilyk \\ m.samilyk@ukr.net
}

Sumy National Agrarian University,

G. Kondratiev Str., 160, Sumy, 40021, Ukraine

\begin{abstract}
The composition of milk and dairy products is considered. Attention is focused on the biological value and physiological significance of cheeses, because they contain the whole spectrum of nutrients, including the irreplaceable ones which necessary for a person for vital processes. Taking into consideration of scientific positions about the necessity of giving the products the functional properties, it is necessary to improve the formulations and traditional methods of cheese production. It is important that this corresponds to the basic principles and directions of the state policy in the field of healthy nutrition. The article proposes a fundamentally new recipe and technology of producing sour-milk soft cheese with enhanced biological value enriched with vitamins, microelements, free amino acids, food fibers. For cheese, which is made using advanced technology, the experimental name "Lubomir» is envisaged. A generalized functional scheme for the production of soft sour milk cheese is presented. The high biological value of the cheese which is obtained by this method is due to the chemical composition of the main components. It is necessary to use raisins from white grapes, walnuts, chicken eggs as components. These components are a source of plastic, energetic and protective substances. The physiological and hygienic significance of nutrients included in its composition is highlighted. The conclusions and main tasks of further researches are determined.
\end{abstract}

Key words: soft sour milk cheese, cheese forming, heat treatment, cooling, milk, eggs, nuts, raisins, cream, vitamins, microelements, free amino acids.

\section{Вступ}

Відома метаморфоза «Сир - творіння природи і мистецтво технолога» десятиріччями не втрачає своєї актуальності. Сучасне сироваріння давно виходить за рамки традиційної технології і все більше удосконалюється, зазнаючи періоду активного розвитку. Досягнуто прогресу в техніці виробництва сиру, управлінні технологічними, мікробіологічними і біохімічними процесами, що призвело до збільшення асортиментного ряду сирної продукції. Природні штами мікроорганізмів у сироварінні замінюють на штами, отримані методами експериментальної селекції, що відповідають сучасним технологічним вимогам виробництва (Mashkin and Parish, 2006).

Натепер наука сиру має ще безліч напрямків для розвитку. Залишається до кінця невирішеним питання класифікації сирів, оскільки деякі сири вітчизняного і закордонного виробництва містять однакові складові компоненти, виготовляються за подібними технологіями, але мають різні назви. Дедалі частіше споживачі віддають перевагу не просто сирам, що мають біологічну, харчову та енергетичну цінність, а й фізіологічну, що повною мірою відповідає потребам збалансованого харчування.

Серед усіх харчових продуктів молоко та молокопродукти є найбільш повноцінними, найбільш збалансованими за незамінними нутрієнтами, які рекомендовано для харчування людей усіх вікових груп. Харчова цінність молока і молокопродуктів обумовлена переважно вмістом у їхньому складі білків, жирів, деяких вітамінів, макро- і мікроелементів (Zubar, 2016).

Найважливішою і найціннішою складовою молока є білки. $80 \%$ усіх білків молока становить казеїн, реш- та (альбуміни і глобуліни) відносяться до сироваткових білків. Саме казеїн, який на 95\% засвоюється організмом людини, є основним компонентом сирів. Фізіологічна цінність сиру підвищується завдяки зв'язкам білкових молекул 3 вітамінами, мінеральними речовинами, а також ліпідами (Gorbatova, 2005).

Вітаміни, як і білки, є незамінними речовинами в харчуванні, оскільки вони відіграють дуже важливу роль у багатьох біохімічних реакціях та процесах засвоєння нутрієнтів. Добова потреба у вітамінах складає: $\mathrm{C}-70$ мг; $\mathrm{B}_{1}-1,7$ мг; $\mathrm{B}_{2}, \mathrm{~B}_{6}-2 \mathrm{мг} ; \mathrm{B}_{9}-200$ мг; РР - 19 мг; $\mathrm{B}_{12}-3$ мкг; біотину - 150 мкг; пантотенової кислоти 5-10 мг; холіну 250-600 мг; А - 1 мг; D - 2,510 мкг; E - 10 мг. Вміст вітамінів у сирах залежить від мікрофлори і технології виготовлення. Деякі вітаміни, що підтримують захисні механізми до інфекцій, беруть участь в окисно-відновних процесах, поліпшують засвоєння білків та еластичність кровоносних судин (С), нормалізують вміст лейкоцитів, підтримують захисну функцію печінки, впливають на обмін речовин у мозку $\left(\mathrm{B}_{12}\right)$, регулюють обмін жирів та білків, запобігають жировому переродженню печінки, впливають на кровотворення $\left(\mathrm{B}_{4}\right)$, руйнуються при тепловій обробці (Zubar, 2016). Таким чином, існує необхідність не лише у збереженні вітамінів в процесі виробництва сиру, а й у збільшенні їх кількості. Крім того, до складу сиру варто вводити інші компоненти, які сприятимуть підвищенню його біологічної цінності.

Мета $i$ завдання дослідження. 3 огляду на узагальнення наукових позицій щодо необхідності надання сирам функціональних властивостей, виникає потреба удосконалення рецептури та традиційних методів виробництва. Технологія виготовлення повинна бути простою та доступною, щоб вартість про- 
дукту не перевищувала наявні на ринку пропозиції асортиментного ряду.

\section{Матеріал і методи досліджень}

Об'єктом наших досліджень обрано м'який кисломолочний сир, що має високу кислотність та високу частку вологи.

Особливістю виробництва кисломолочних сирів $є$ застосування кислотного, термокислотного і кислотно-сичужного способів коагуляції білків молока, температури пастеризації до $85^{\circ} \mathrm{C}$. Технологія кисломолочного сиру подібна $з$ технологією сиру домашнього. Одним із видів даного продукту є кминний сир «Кіменю», що виготовляється 3 масовою часткою жиру в сухій речовині 10, 20 і 40\%. Технологічний процес виробництва сиру «Кіменю» складається із таких операцій: підготовка сировини, теплова обробка і приготування суміші, формування, пакування і маркування. Як сировину використовують незбиране або знежирене молоко, сир, вершки, яйця, сіль та кмин (Bredikhin and Yurin, 2007).

Нами запропонована удосконалена технологія виготовлення кисломолочного сиру із незбираного молока 3 додаванням волоських горіхів, яєць курячих та родзинок. Для сиру, виготовленого за цією технологією, пропонується використання експериментальної назви «Любомир». Принципова технологічна схема виробництва сиру показана на рис. 1.

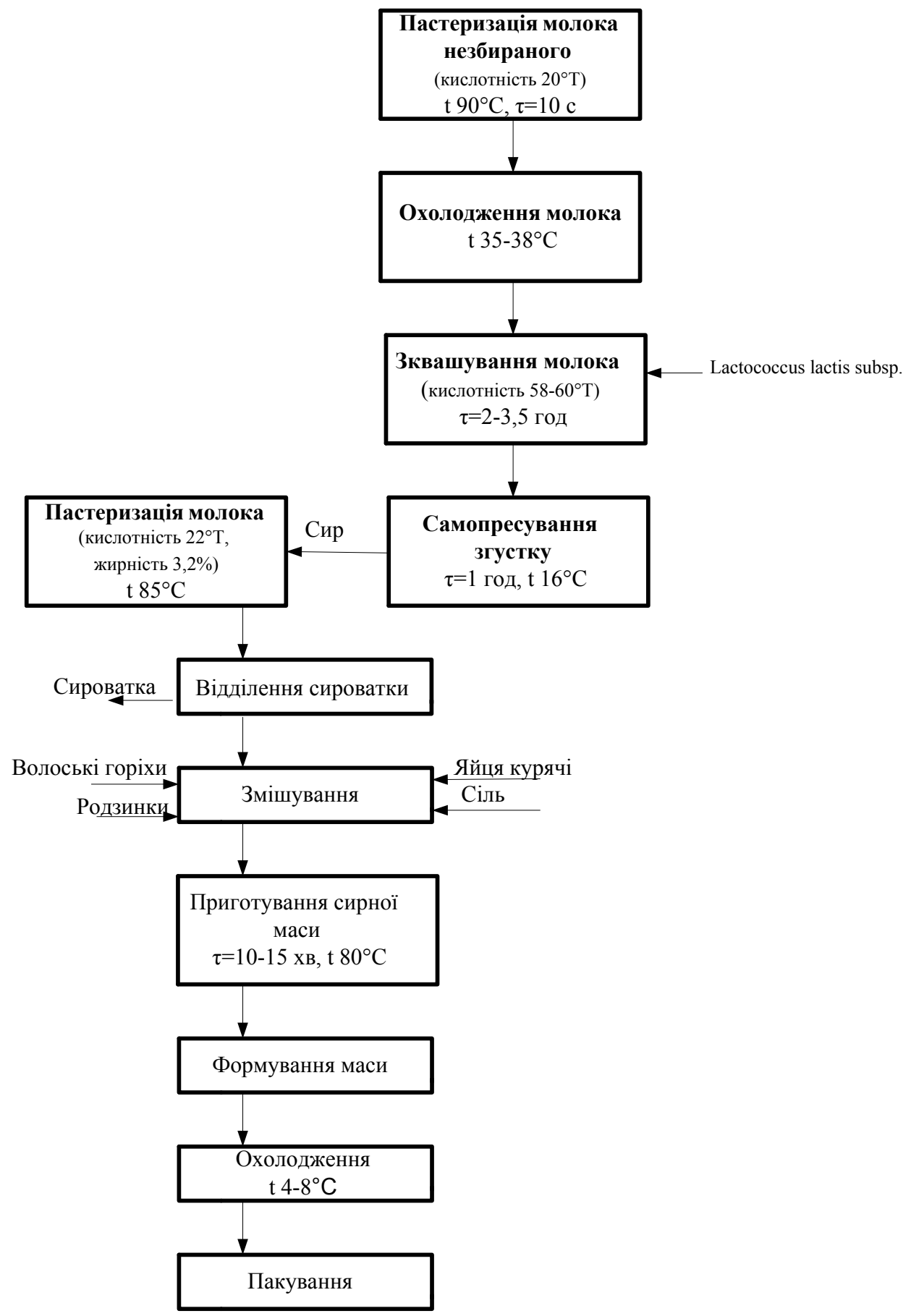

Рис. 1. Узагальнена функціональна схема виробництва сиру кисломолочного «Любомир» 


\section{Результати та їх обговорення}

Удосконалена рецептура невизріваючого кисломолочного сиру передбачає збагачення його складу вітамінами, вуглеводами, органічними кислотами, мікроелементами, харчовими волокнами тощо.

Висока біологічна цінність сиру, отриманого запропонованим способом, обумовлена хімічним складом та впливом на організм людини його основних компонентів.

У яйцях містяться незамінні та добре збалансовані нутрієнти. Білки яєць містять усі незамінні амінокислоти і тому є міжнародним еталоном якості білка. Засвоюваність білків яєць становить 98\%, причому вони після теплової обробки засвоюються краще, ніж сирі. Білок авідин блокує вітамін Н (біотин), але при термічній денатурації він втрачає свій негативний вплив (Zubar, 2016).

Запропонована нами технологія передбачає температурну обробку сирної маси після змішування всіх компонентів, тому біотин в готовому продукті зберігається.

Жовток яйця є джерелом жирів, холіну і фосфоліпідів, які запобігають атеросклерозу і жировому переродженню печінки. Яйця містять значну кількість холестерину, але він сприятливо збалансований 3 антиатерогенними нутрієнтами - лецитином, лінолевою кислотою, вітамінами. Особливо багаті яйця на вітаміни A, D, B $2, B_{12}$ і фолієву кислоту. Крім того, яйця, особливо жовток, - важливе джерело Фосфору, Сірки, Цинку, Міді та інших добре засвоюваних мінеральних елементів (Zubar, 2016).

Для формування пікантного смаку сиру «Любомир», збагачення його харчовими волокнами та органічними кислотами нами запропоновано використовувати як наповнювач родзинки із білого винограду.

Родзинки мають багатий вітамінний склад (А, C, Е, Н, бета-каротин, групи В), містять харчові волокна, макро- і мікроелементи - Калій, Кальцій, Магній, Натрій, Фосфор, Хлор, Залізо, Марганець, Мідь, Селен, Цинк (Zubar, 2016).

Харчові волокна відіграють важливу роль у детоксикації організму, адсорбції та виведенні з організму холестерину й жовчних кислот, радіонуклідів, канцерогенних та інших речовин. Вони регулюють стан і функції шлунково-кишкового тракту, сприяють розвитку нормальної кишкової мікрофлори. Особливо багаті родзинки Калієм, тому вони корисні для підтримки нормального складу крові, роботи серцевого м'язу та нирок, поліпшення передачі нервових імпульсів і обміну речовин у шкірі. Завдяки вмісту нікотинової кислоти родзинки заспокоюють і регулюють роботу нервової системи (Zubar, 2016).

Всі корисні властивості волоських горіхів зберігаються після висушування. До складу горіхів входять: жири у діапазоні 45-77\%, білки 8-21\%, вуглеводи до $10 \%$ і вода до 5\%. Калорійність складає 648 ккал на 100 г продукту. В ядрах горіха містяться вільні амінокислоти (аспарагін, валін, глутамін, гістидин, серин, фенілаланін і цистин), провітамін А, вітаміни Е, РР, К, групи В, а також мінеральні речовини і мікроелементи (Йод, Кальцій, Калій, Кобальт, Магній, Залізо,
Цинк, Фосфор). Горіх волоський має загальнозміцнюючу, антисклеротичну, полівітамінну, антисептичну дії, покращує травлення, матково-плацентарний кровообіг у вагітних з гіпоксією плоду. У 100 г горіхів міститься 12,3 мкг кобальту (Со). Кобальт відноситься до незамінних елементів, що входять до складу ферментів, гормонів, вітамінів та стимулює утворення гемоглобіну й еритроцитів, бере участь в утворенні інсуліну, активує кишкову i кісткову фосфатазу (Zubar, 2016).

Оскільки якість продукту обумовлена сукупністю властивостей, що відображають органолептичні показники, безпечність та здатність забезпечувати потреби організму у харчових речовинах, можна стверджувати, що сир «Любомир» може стати продуктом високої якості.

\section{Висновки}

1. Біологічна цінність сиру обумовлена вмістом у ньому життєво необхідних речовин (вітамінів, мікроелементів, незамінних жирних кислот, харчових волокон).

2. Додавання яєць поліпшує органолептичні показники продукту, збагачує його вітамінами $\mathrm{A}, \mathrm{D}, \mathrm{B}_{2}$, $\mathrm{B}_{12}, \mathrm{~B}_{4}$ і фолієвою кислотою.

3. 3 метою збагачення сиру харчовими волокнами та органічними кислотами пропонується використовувати як допоміжний компонент родзинки із білого винограду.

4. Використання волоських горіхів, сприяє підвищенню вмісту мікроелементів у сирі (J, Ca, K, Co, Mg, Fe, Zn, P).

5. М'який кисломолочний сир пропонується виготовляти кислотно-сичужним способом коагуляції білків молока. Висока температура пастеризації молока $\left(90{ }^{\circ} \mathrm{C}\right)$ дозволить підвищити вихід сиру на 20 $25 \%$.

6. Сир «Любомир» відноситься до невизріваючих сирів, він швидко готується, тому процес його виготовлення не вимагає значних виробничих витрат.

Перспективи подальших досліджень. Предметом наших подальших досліджень $є$ удосконалення рецептури сиру «Любомир» з метою виявлення оптимальної кількості допоміжних компонентів (яєць, горіхів, родзинок). Крім того, планується розширення асортименту м'яких кисломолочних сирів шляхом збагачення їх іншими корисними, біологічно цінними складовими.

Необхідно провести ряд експериментів щодо виявлення оптимального матеріалу форм для самопресування та пакування сиру.

Для забезпечення процесу приготування сирної маси слід розробити конструкцію мішалки з одночасним перемішуванням та нагріванням продукту.

\section{Бібліографічні посилання}

Zubar, N.M. (2016). Fundamentals of Physiology and Food Hygiene: Textbook. K.: Center for Educational Literature (in Ukrainian). 
Bredikhin, S.A., Yurin, V.N. (2007). Technique and technology of production of butter and cheese. Moscow: KolosS (in Ukrainian).

Mashkin, M.I., Parish, N.M. (2006). Technology of Milk and Dairy Products Production: Educational Edition. $\mathrm{K}$.: Higher education (in Ukrainian).
Gorbatova, K.K. (2005). Biochemistry of milk and dairy products. Moscow: Light and food industry (in Ukrainian).

Received 15.09.2017

Received in revised form 16.10.2017

Accepted 20.10.2017 